\title{
Dynamics of yolk sac and oil droplet utilization and behavioural aspects of swim bladder inflation in burbot, Lota lota L., larvae during the first days of life, under laboratory conditions
}

\author{
K. Palińska-Żarska $\cdot$ D. Żarski $\cdot$ S. Krejszeff $\cdot$ J. Nowosad $\cdot$ \\ M. Biłas $\cdot$ K. Trejchel $\cdot$ D. Kucharczyk
}

Received: 3 February 2013/Accepted: 13 June 2013 / Published online: 28 June 2013

(C) The Author(s) 2013. This article is published with open access at Springerlink.com

\begin{abstract}
The study concerns investigation of early larval development of burbot, Lota lota. As part of a two-year study, the first 15 days (until the end of yolk sac resorption) of burbot larvae development under controlled conditions were examined. The aim of the study was to observe the moment of swim bladder inflation and the behavioural aspects of this process, as well as the analysis of yolk and oil droplet resorption and the beginning of exogenous nutrition. It was observed that larvae began to inflate their swim bladder on the 3rd day posthatch. On $5 \mathrm{DPH}$, none of the larvae without an inflated bladder was able to swim up the distance separating it $(10 \mathrm{~cm})$ from the water surface. Since $9 \mathrm{DPH}, 50 \%$ of larvae started exogenous feeding, and the absence of yolk was observed on $13 \mathrm{DPH}$ and oil droplet on 14 DPH, while on $15 \mathrm{DPH}, 100 \%$ of feeding larvae were observed. The presented results indicate that the analyzed period is critical for burbot, and it is characterized by a high mortality rate (over $60 \%$ ). Additionally, the results suggest that, under controlled conditions, the latest moment when burbot larvae should be given exogenous food is 9-10 DPH and until the moment of the swim bladder inflation, larvae should be kept in tanks with a low water depth (up to $10 \mathrm{~cm}$ ). The data presented in this study could have a significant influence on the efficiency of larvae rearing, both for aquaculture and for restocking purposes.
\end{abstract}

Keywords Lota lota $\cdot$ Larvae $\cdot$ Biology $\cdot$ Swim bladder $\cdot$ Oil droplet $\cdot$ Yolk

\section{Introduction}

Burbot, Lota lota L., is the only freshwater representative of the Gadidae family, found almost in the entire Holarctic (McPhail and Paragamian 2000). It is one of the stenothermal predators preferring mainly cold rivers (Paragamian et al. 2008; Paragamian and Hansen

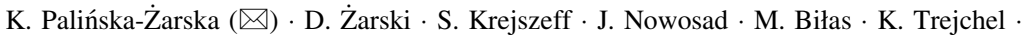

D. Kucharczyk

Department of Lake and River Fisheries, University of Warmia and Mazury in Olsztyn,

ul. Oczapowskiego 5, 10-719 Olsztyn, Poland

e-mail: katarzyna.palinska@uwm.edu.pl
} 
2009). However, it can be also found in brackish waters near river estuaries and in deep lakes (Scott and Crossman 1973; McPhail and Paragamian 2000; Hardy et al. 2008; Koporikov and Bogdanov 2011). Currently, mainly due to river regulations, over-fishing, thermal anomalies and pollutions, the burbot has become an endangered species over almost the entire area of its occurrence (Lauri et al. 1998; Kjellman and Eloranta 2002; Kjellman 2003; Paragamian et al. 2008; Hardy et al. 2008). The constantly decreasing size of the burbot population in the natural environment and the rapidly increasing interest in intensive aquaculture of this species (due to the high price, liver considered as a delicacy and tasty boneless flesh) created the urgent need for development of effective procedures of production of fry under controlled conditions (Wolnicki 2001; Wolnicki et al. 2002; Harzevili et al. 2003; Żarski et al. 2009, 2010; Jensen et al. 2011; Trabelsi et al. 2011; Wocher et al. 2011).

The larval period is one of the most crucial life stages of a fish. The changes occurring during this relatively short period affect the entire adult life. The larval period is related to a high mortality rate, which is often attributed to a combination of external (e.g. temperature, pressure, $\mathrm{pH}$, amount of food, intensity of predation) and internal (e.g. behavioural) factors (Fuiman and Cowan 2003). Additionally, the first days of the larvae life is the time when the swim bladder must be inflated, and this moment is considered to be one of the most critical (Egloff 1996; Czesny et al. 2005). It is known that burbot is the physoclisti (with closed swim bladder) fish and its swim bladder has only one chamber (Jones and Marshall 1952; Grodziński 1971). Therefore, in physoclisti fish the pneumatic duct closes at some stage of larval life and cuts the swim bladder from digestive tract. However, in burbot larvae, the moment when the pneumatic duct closes is not very well known and described. Moreover, during the larval period, many species of fish have very poorly developed digestive tract, due to which their digestion is disabled. This is related to the need for providing to the larvae exogenous digestive enzymes with food (Dạbrowski 1984; Galavíz et al. 2011). The knowledge of larval biology in this crucial period of life is a key element of effective larviculture, which directly affects the quality of fry and later of adult animals (Øyvind et al. 2011). To date, the data regarding this aspect are very limited, and there is no information about this critical period in burbot.

To date, there is lack of highly effective procedures of larviculture of the burbot. One of the biggest problems is still the early larval stage, during which a very high mortality rate was observed (even above $70 \%$ ), both in the natural environment and under controlled conditions (Schran 1983; Ghan and Sprules 1991; Żarski et al. 2009). Therefore, the knowledge of the biology of the first days of the burbot larvae life may be crucial for effective intensive larviculture of the species. Especially, ineffective procedures applied in the first days of life may affect growth differentiation and in consequence may lead to increased level of cannibalism, which is very problematic in the case of burbot (Jensen et al. 2011; Trabelsi et al. 2011) similar to other predators (Baras et al. 2003). The published data include a series of studies related to rearing larvae of this species under controlled conditions. They concerned determination of the basic rearing conditions, such as stock density (Wolnicki 2001; Kujawa et al. 2002a, b), optimum temperature and photoperiod (Wolnicki et al. 2002; Harzevili et al. 2004) or the type of the food supplied (Harzevili et al. 2003; Żarski et al. 2009; Wocher et al. 2011). Most of the studies concerning early larval development (from the moment of hatching to the moment of exogenous feeding) refer to the Salmonidae and some species of the Cyprinidae, such as the common carp, Cyprinus carpio L., the crucian carp, Carassius carassius (L.) or the chub, Leuciscus cephalus (L.) (Mark et al. 1987; El-Finky and Wieser 1988; Laurila and 
Holopainen 1990; Çalta 2000), as well as commercially exploited marine species (Williams et al. 2004). However, studies focusing on biological aspects of early development of burbot larvae (up to the beginning of exogenous feeding) are missing.

In this study, the first 15 days of development of burbot larvae under controlled conditions (until the moment of exogenous feeding) were examined. Within the present study morphometry of larvae, dynamics of inflation of swim bladder and the behavioural aspect of this process as well as the character of yolk and oil droplet resorption along with the beginning of exogenous feeding were analyzed.

\section{Materials and methods}

Broodstock and freshly hatched larvae management

The research was carried out twice in two subsequent years, following the same protocol. The research material were larvae obtained as a result of artificial spawning of fish originating from the Odra River (north-eastern Poland). Brood fish for reproduction were stimulated only through manipulation of thermal conditions, according to the methodology described by Żarski et al. (2010). Each year, eggs obtained from three females of an average weight of $720 \pm 108 \mathrm{~g}$ were fertilized with semen from three males with an average weight of $332 \pm 79 \mathrm{~g}$. For the first month, the eggs were incubated in Weiss jars, below $4{ }^{\circ} \mathrm{C}$. After that period, until the moment of hatching the water temperature was $6{ }^{\circ} \mathrm{C}$. At the moment when the first spontaneously hatched larvae were observed, eggs were transferred to water at $10-12{ }^{\circ} \mathrm{C}$ in order to synchronize hatching (as described by Żarski et al. 2009). Observations were carried out until day 15 post-hatch (DPH).

\section{Rearing conditions}

After hatching, the larvae were moved to a semi-closed laboratory recirculating system, where they were placed in a 150-L tank. The initial stocking density of larvae (determined by the volumetric method) was 150 ind. $\mathrm{L}^{-1}$. The system was equipped with biological filtration, aeration and automatic temperature regulation $\left( \pm 0.1^{\circ} \mathrm{C}\right)$. For the entire period of research, water temperature in the tank was $12{ }^{\circ} \mathrm{C}$. Such a thermal regime was recommended as optimal for burbot larvae (Wolnicki et al. 2002). The photoperiod for the entire period of research was $24 \mathrm{~h}$ (24L:0D). Ammonia content (measured every 3 days with the use of HI 83200 photometer, Hanna Instruments, Italy) for the entire period of rearing was below $0.01 \mathrm{mg} \mathrm{L}^{-1}$. Oxygen content was measured twice a day (using oxygen meter Handy Polaris 2.0 OxyGuard, Denmark), and no decrease below $80 \%$ saturation was observed for the entire period of the experiment. The determination of the percentage of larvae which started exogenous feeding began on day 4 post-hatch (DPH). For this purpose, 30 larvae were transferred to a separate 1-L beaker and provided with 1,000 of freshly hatched Artemia sp. nauplii (San Francisco origin). After $1 \mathrm{~h}$, the percentage of larvae with filled digestive tract was then calculated. The feeding of all larvae (about 200 nauplii per capita per day) was initiated when at least $50 \%$ of the larvae started exogenous feeding. Food was provided continuously with the use of an automatic feed dispenser which was intensively aerated in order to mix the content (operating as a drip feed with adjusted flow). The feed dispenser was replenished three times a day. 
Rearing tanks were cleaned every day in the morning. Due to the large number of smallsized larvae, it was not possible to precisely determine the number of dead larvae (especially after initiating feeding), since dead specimens very quickly underwent partial decomposition. The moment when mortality began was recorded. The final survival rate of larvae was calculated at the end of the experiment by determining the number of larvae using the volumetric method.

Larvae sampling and measurements

Starting with the moment of hatching (0 DPH) until $15 \mathrm{DPH}, 30$ specimens were randomly collected to carry out measurements. In order to do that, anesthetized (in the MS-222 solution at a dose of $150 \mathrm{mg} \mathrm{L}^{-1}$ ) larvae were photographed under a stereoscopic microscope (Leica MZ 12.5, Switzerland), using image acquisition and analysis software, ProgRes ${ }^{\circledR}$ CapturePro 2.5 (Jenoptic, Germany). This software was also used to carry out measurements $( \pm 0.1 \mathrm{~mm})$. Anesthetized larvae on which the measurements were performed did not return to the rearing tanks.

Each day, larvae were weighed (after gently draining off on filter paper) in three replications, 10 fish at a time, and the mean wet weight of a single specimen was then calculated. Every day, swim bladder inflation rate was also determined and the total length of larvae (TL), yolk sac length (YsL), yolk sac height (YsH), oil droplet diameter (OdD) as well as swim bladder length ( $\mathrm{SbL})$ and height $(\mathrm{SbH})$ were measured (Fig. 1).

The volume of oil droplet was then measured (VOd) by applying the formula for the volume of a sphere:

$$
\operatorname{VOd}=1 .(3) \pi r^{3}
$$

where $r$ is the oil droplet radius.

Additionally, the volume of yolk sac (VYs) and the volume of swim bladder (VSb) were measured, using the formula for the volume of an ellipsoid (e.g. Williams et al. 2004):

$$
\mathrm{VYs} \text { and } \mathrm{VSb}=1 .(3) \pi a b c,
$$

where $\mathrm{a}-0.5$ of yolk sac or swim bladder length, $\mathrm{b}$ and $\mathrm{c}-0.5$ of yolk sac or swim bladder height.

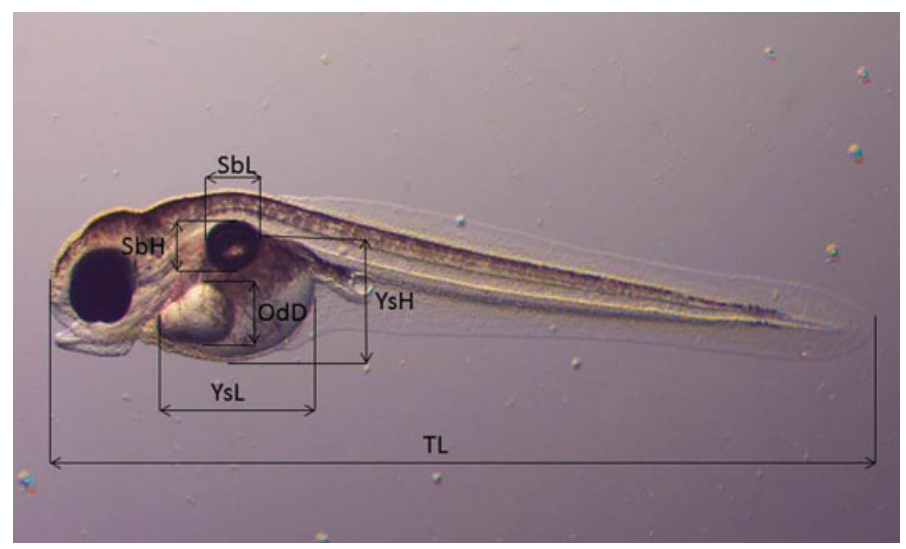

Fig. 1 A burbot larva with an inflated swim bladder 6 DPH: $T L$ total length, $Y s L$ yolk sac length, $Y s H$ yolk sac height, $S b L$ swim bladder length, $S b H$ swim bladder height, $O d D$ oil droplet diameter 
The volume of yolk (VY) was then calculated by deducting the volume of the oil droplet located inside the yolk sac from the volume of the yolk sac (VY = VYs - VOd).

\section{Behavioural observation of larvae}

Each morning (starting on $1 \mathrm{DPH}), 100$ larvae were sampled at randomly from the rearing tank and then placed in a tank for behavioural analysis $(30 \times 10 \times 20 \mathrm{~cm})$. One wall of the tank was pasted with a black and white chequered pattern, with squares of the $0.5 \mathrm{~mm}$ sides. In this tank, the height of the water column was $10 \mathrm{~cm}$. A camcorder (Sony HDRSR8) was placed in front of the tank at a distance of $20 \mathrm{~cm}$. The camcorder field of vision was adjusted so that the angle of camcorder inclination towards the tank made it possible to observe the bottom, the water column and the water surface from the bottom. Fifteen minutes after placing larvae in the tank (the period of time necessary for larvae not to demonstrate movements resulting from manipulation), a 30-min recording was made. After recording, larvae were placed again in the rearing tank.

On the basis of film documentation (each time on the base of 100 specimens), the number of "approaches" of larvae to the water surface was determined, from the moment of lifting from the bottom of the tank to the moment of falling again on the bottom. Moreover, the distance (in $\mathrm{cm}$ ) which larvae were able to pass at one time from the moment of lifting from the bottom was determined. Additionally, the time of active swimming of larvae (min) and the time of resting on the bottom of the tank were calculated (min).

Data analysis and statistics

Statistical differences between particular groups were analyzed by one-way analysis of variance (ANOVA) and Tukey's post hoc test at the significance level below $5 \%$ $(P<0.05)$. Correlations between values of parameters recorded $(\mathrm{TL}, \mathrm{OdV}, \mathrm{YV}, \mathrm{SbV}$ and Time of active swimming, Time of resting on the bottom) were studied using regression analysis. Statistical analysis was conducted using Microsoft Excel and STATISTICA (data analysis software system), version 10 .

\section{Results}

Weight of larvae

No significant increase in the larvae weight was found $(P>0.05)$ during the period of observation. However, a weight decrease tendency was observed from the day of hatching $(0 \mathrm{DPH}-0.67 \mathrm{mg}$ ) to the day when less than $20 \%$ of larvae fed on exogenous food ( 7 $\mathrm{DPH}-0.26 \mathrm{mg}$ ). Afterwards, it was established that the weight increased from the moment when $40 \%$ of larvae began exogenous feeding ( $8 \mathrm{DPH})$ to the last day of research (15 $\mathrm{DPH}$ ), when the mean weight of a larvae was $1.02 \pm 0.17 \mathrm{mg}$ (Fig. 2).

Length of larvae

Between the day of hatching and $15 \mathrm{DPH}$, the total length (TL) of the burbot larvae body grew continuously and increased by $1.56 \mathrm{~mm}$ (a mean length was 3.97 and $5.53 \mathrm{~mm}$ in 0 $\mathrm{DPH}$ and $15 \mathrm{DPH}$, respectively). Until $7 \mathrm{DPH}$, the TL of larvae was comparable to the TL 


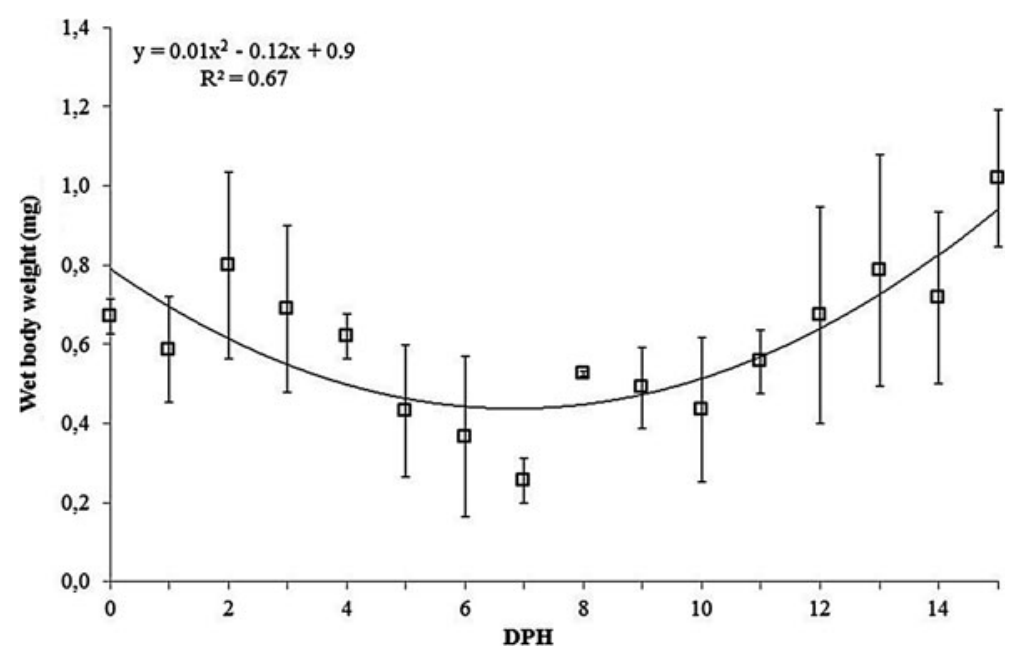

Fig. 2 Changes in burbot larvae weight during first 15 days of development (0-15 DPH). No statistical differences were found among the whole experimental period $(P>0.05)$

of larvae on the day of hatching (0 DPH). Only on 8 DPH could it be claimed that TL was higher as compared to $0 \mathrm{DPH}$. Although TL increased constantly, there were no differences $(P>0.05)$ until 14 DPH (Fig. 3).

Time of active swimming and resting

One day after hatching (1 DPH), the larvae sporadically swam up from the bottom and the time of active swimming in the water column averaged 3.3 min during a 30-min observation period. A similar behaviour of larvae was also observed on $2 \mathrm{DPH}$. After $3 \mathrm{DPH}$, an increase in the activity of larvae was observed, which swam on average for $21.2 \mathrm{~min}$. From

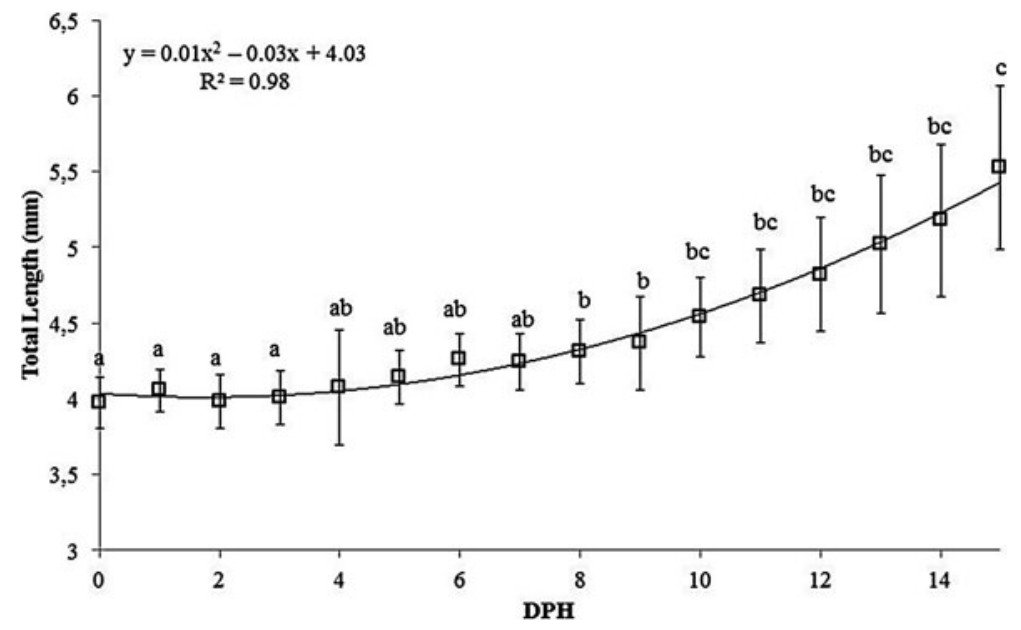

Fig. 3 Changes in total length (TL) during first 15 days of development (0-15 DPH). Data marked with different letters were statistically different $(P<0.05)$ 


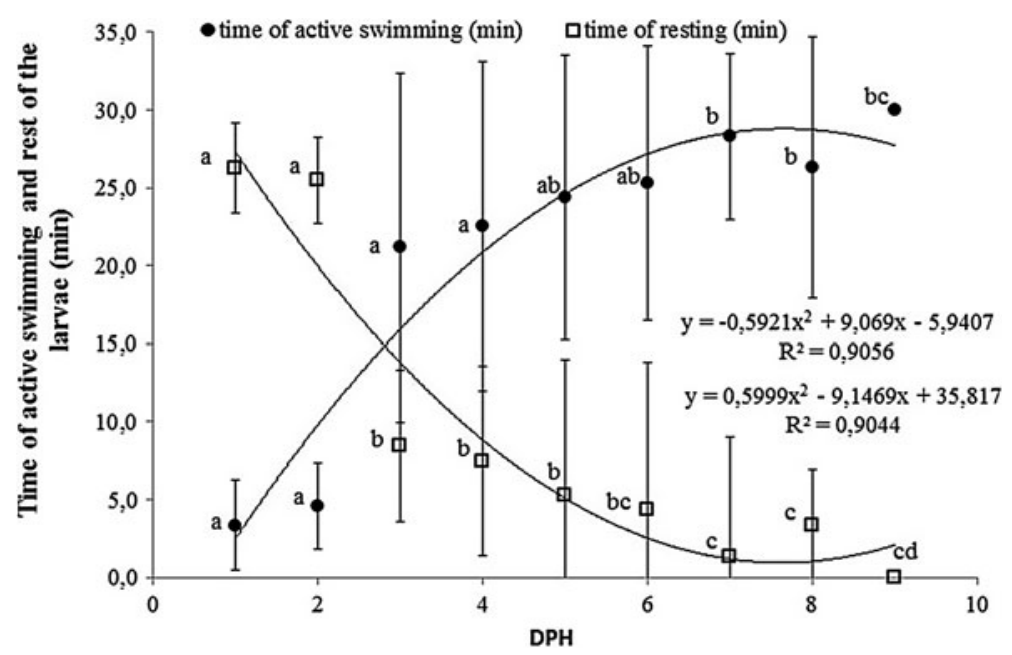

Fig. 4 Time of active swimming and resting of a burbot larvae on the bottom during the first 10 days of development $(0-10 \mathrm{DPH})$. Data marked with different letters were statistically different $(P<0.05)$

that moment, the time spent by larvae on active swimming increased at a much lower rate, until $9 \mathrm{DPH}$, when larvae swam in an active way for the entire $30 \mathrm{~min}$ of observation (Fig. 4).

On the other hand, the time spent by larvae on the bottom of the tank showed an opposite tendency. On $1 \mathrm{DPH}$, most burbot larvae lay on the bottom for $26.7 \mathrm{~min}$ on average during the 30 min observation period, just like on $2 \mathrm{DPH}$. On $3 \mathrm{DPH}$, the time spent by larvae on resting on the bottom of the tank rapidly decreased to $8.4 \mathrm{~min}$. Since then, a gradual decrease in the mean time of larvae resting on the bottom was observed, until 9 DPH (Fig. 4).

Number of larvae swimming to the surface before falling to the bottom and distance made "at one time"

The first day after hatching (1 DPH), burbot larvae lay on the bottom and occasionally made some time rapid movements with the entire body, which allowed them to swim up from the bottom. They were able to swim from the bottom on average to the height of about $4 \mathrm{~cm}(P<0.05)$ and undertook 7 such attempts during the 30-min observation period. On 2 and $3 \mathrm{DPH}$, the average covered distance grew to over $7 \mathrm{~cm}$, and the number of attempts to swim up to the surface was higher than on 1 DPH by at least 3 approaches. On 4 and 5 DPH, larvae were able to pass "at one time", on average, about $8 \mathrm{~cm}$ and the number of their attempts to reach the surface was the highest on those days (17 and 18 times on 4 and $5 \mathrm{DPH}$, respectively). Between 6 and $8 \mathrm{DPH}$, there were no larvae observed which would be able to reach the water surface (on $6 \mathrm{DPH}$, they were able to cover, an average, the distance of about $3.62 \mathrm{~cm} ; 7 \mathrm{DPH}-2.95 \mathrm{~cm} ; 8 \mathrm{DPH}-1.92 \mathrm{~cm} ; P<0.05$ ) (Table 1). On $9 \mathrm{DPH}$, the only larvae observed at the bottom of the tank were the ones that were not able to inflate their swim bladders or to lift from the bottom. And they could only make rare twitching movements with their entire body. 
Table 1 Number of attempts to swim up to the surface and the distance covered "at one time" (cm) by burbot larvae during the first $8 \mathrm{DPH}$

The values are expressed as mean \pm SD. Data in columns marked with different letters differed from each other $(P<0.05)$

The letters a, b, c are the way of expressing statistical differences

\begin{tabular}{lcclll}
\hline DPH & $\begin{array}{l}\text { Number of swimming to the surface } \\
\text { before falling to the bottom }\end{array}$ & \multicolumn{2}{l}{$\begin{array}{l}\text { Distance made at "one } \\
\text { time” }(\mathrm{cm})\end{array}$} \\
\cline { 2 - 3 } \cline { 5 - 5 } & Mean & SD & & Mean & SD \\
\hline 1 & $7^{\mathrm{a}}$ & 8.47 & & $4.73^{\mathrm{a}}$ & 2.7 \\
2 & $11^{\mathrm{a}}$ & 10.66 & $7.4^{\mathrm{b}}$ & 2.33 \\
3 & $10^{\mathrm{a}}$ & 7.59 & $7.27^{\mathrm{b}}$ & 2.16 \\
4 & $17^{\mathrm{ab}}$ & 11.37 & $8.23^{\mathrm{b}}$ & 2.07 \\
5 & $18^{\mathrm{b}}$ & 10.63 & $8.32^{\mathrm{b}}$ & 2.17 \\
6 & - & - & $3.62^{\mathrm{c}}$ & 2.45 \\
7 & - & - & $2.95^{\mathrm{c}}$ & 2.2 \\
8 & - & - & $1.92^{\mathrm{c}}$ & 1.63 \\
\hline
\end{tabular}

Volume of oil droplet, swim bladder and yolk, mortality

Inflation of the swim bladder started on day 3 post-hatch (3 DPH), when $17 \%$ of larvae inflated their bladders. With each subsequent day, the percentage of larvae with inflated bladder increased. On $5 \mathrm{DPH}$, the inflated bladder was found in over $50 \%$ specimens. At $15 \mathrm{DPH}$, an inflated bladder was observed in $100 \%$ of larvae (Fig. 5).

The initiation of exogenous feeding was observed on $5 \mathrm{DPH}$, when $10 \%$ of larvae had their digestive tract filled. From that moment, a constantly growing trend in the number of larvae taking food was observed. On $9 \mathrm{DPH}$, exogenous food was taken by $50 \%$ of the larvae. Taking exogenous food in all larvae was recorded only on 15 DPH (Fig. 5).

Mortality among larvae was observed after 6 DPH (Fig. 5). On the last day of observation, a mortality rate of $70 \%$ and $60 \%$ was recorded in the first and second year of research, respectively.

After the moment of initiating swim bladder inflation (3 DPH), a constant increase in its volume was observed. At the moment when larvae inflated their bladder, its mean volume

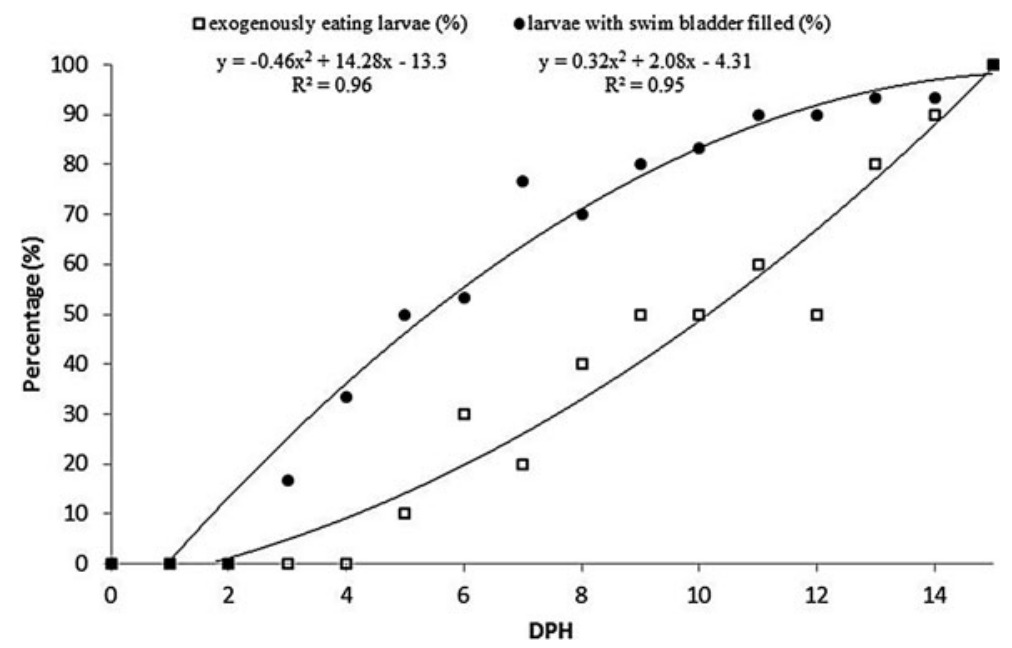

Fig. 5 The percentage of burbot larvae with an inflated swim bladder and percentage of larvae which started exogenous feeding in relation to the development day 


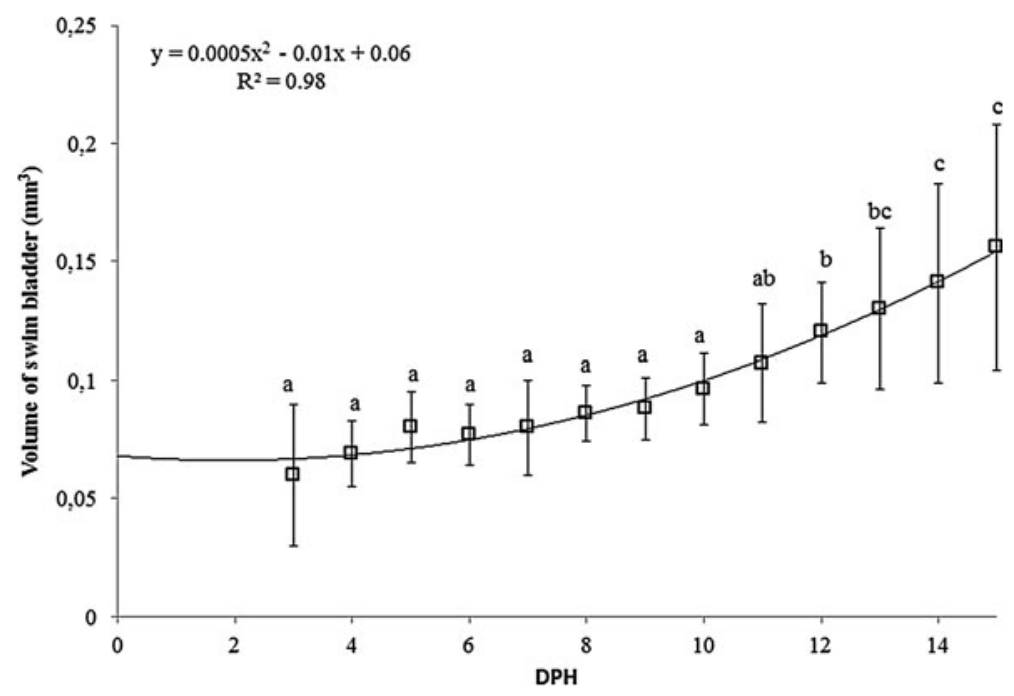

Fig. 6 The volume of the swim bladder (VSb) of burbot larvae from the moment of initiating swim bladder inflation 3-15 DPH. Data marked with different letters were statistically different $(P<0.05)$

(VSb) was $0.06 \mathrm{~mm}^{3}$, while on $15 \mathrm{DPH}$, it was already $0.16 \mathrm{~mm}^{3}$. Between 3 and $10 \mathrm{DPH}$, the values of $\mathrm{VSb}$ in larvae, despite a regular increase, were similar $(P>0.05)$. Only on 11,12 and $13 \mathrm{DPH}$, differences were observed $(P<0.05)$ in comparison with the first 7 days, when larvae had inflated their swim bladders (3-10 DPH). The highest volume of the swim bladder was found on 14 and 15 DPH (Fig. 6).

The volume of yolk (VY) on $0 \mathrm{DPH}$ was $71.6 \mu \mathrm{m}^{3}$, while on the last day when the presence of yolk was still found (13 DPH), VY was $1.3 \mu^{3}$. On the hatching day (0 DPH) and $1 \mathrm{DPH}, \mathrm{VY}$ in larvae was the highest and it significantly differed $(P<0.05)$ from its volume on subsequent days (2-15 DPH). Between 2 and $6 \mathrm{DPH}$, despite the steadily dropping values of VY, no distinctive changes were observed $(P>0.05)$. On the other hand, the lowest values of the VY parameter were observed between 7 and $13 \mathrm{DPH}$, when no yolk presence was found (Fig. 7).

The volume of oil droplets (VOd) on 0 DPH was lower than the volume of yolk and it amounted, on average, to $17.8 \mu^{3}$. Nevertheless, it was observed for one day more, until $14 \mathrm{DPH}\left(0.84 \mu^{3}\right)$. At hatching $(0 \mathrm{DPH})$ and on $1 \mathrm{DPH}$, the values of the VOd parameter did not significantly differ $(P>0.05)$. In addition, no significant differences were observed $(P>0.05)$ in spite of the constantly decreasing volume of the oil droplets between $2 \mathrm{DPH}$ and $6 \mathrm{DPH}$. The lowest volume of the oil droplets was observed on $14 \mathrm{DPH}$, but it did not significantly differ from the value of this parameter on 7-13 DPH (Fig. 7).

On $15 \mathrm{DPH}$, no oil droplet or yolk was observed in larvae. This was also the moment when $100 \%$ of larvae had already fed on exogenous food and no dead larvae were recorded (Figs. 5, 7).

\section{Discussion}

Burbot larvae are a pelagic and one of the smallest larvae among freshwater fish species (Grodziński 1971; Urho 2002). In the present study, they had only $3.97 \mathrm{~mm}$ long 


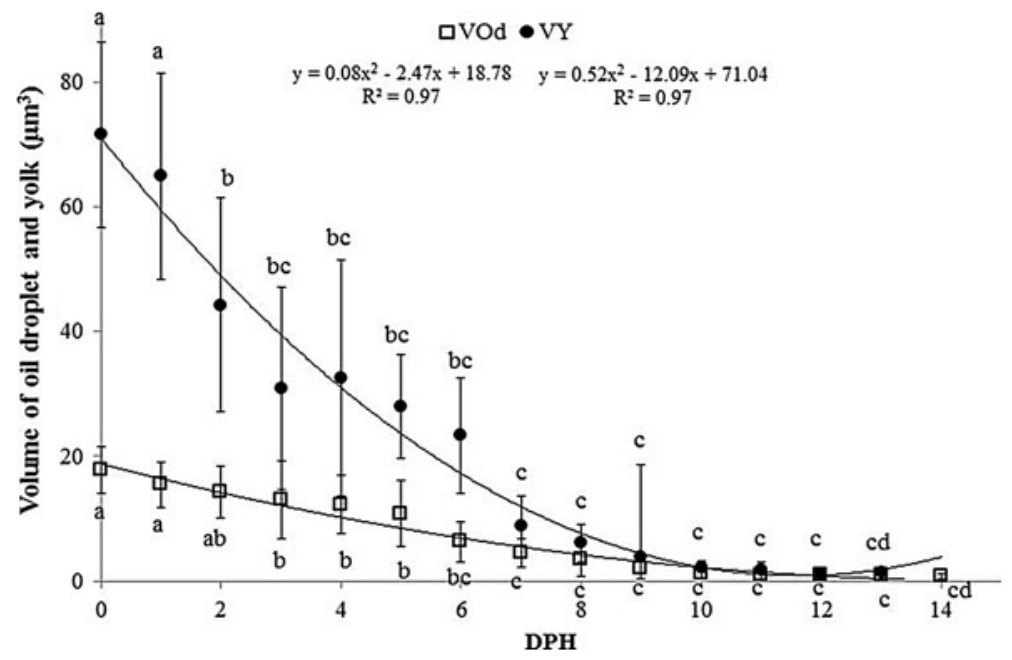

Fig. 7 Changes in the volume of oil droplet (VOd) and yolk (VY) in burbot larvae during 15 days of development $(0-15 \mathrm{DPH})$. Data marked with different letters were statistically different $(P<0.05)$

immediately after hatching (0 DPH), while, for example, freshly hatched larvae of the crucian carp, which are ones of the smallest larvae of the Cyprinidae, are over $5 \mathrm{~mm}$ long (Laurila and Holopainen 1990; Żarski et al. 2011b). Even larvae of a marine fish species of the same family as the burbot-the cod, Gadus morhua L., are larger $(4.8 \mathrm{~mm})$ at the moment of hatching as compared to burbot (von Herbing et al. 1996). A similar length of burbot larvae to those recorded in this study at the moment of hatching has previously been reported (Fisher 1999). A small body size also results in a very low weight of burbot larvae. On $0 \mathrm{DPH}$, the mean wet weight was $0.67 \mathrm{mg}$. Almost the same small weight immediately after hatching is found in larvae of the percids, e.g. the perch, Perca fluviatilis L., weighing about $0.7 \mathrm{mg}$ (Babiak et al. 2004) and the pikeperch, Sander lucioperca (L.), weighing about $1 \mathrm{mg}$ (Wang et al. 2009), whereas, for instance, the mean weight of a crucian carp larvae after resorption of the yolk sac was $0.9 \mathrm{mg}$ (Żarski et al. 2011b) and the chub was about $3.4 \mathrm{mg}$ (Çalta 2000). The results obtained confirm previous reports of the small sizes of burbot larvae, which indicate the need to dedicating special attention to those larvae during this period. It involves providing them with appropriate environmental conditions and is connected with the occurrence of a range of manipulation-related problems.

During the observations carried out between 1 and $15 \mathrm{DPH}$, a constant growth of the length of time which larvae spent on active swimming was observed and consequently, a decrease in the time when the larvae rested on the bottom of the tank. On the first day after hatching, the larvae were so weak that they could only lift several times from the bottom of the tank, but they had no energy to pass even a half of the distance to the water surface. On the other hand, the highest effectiveness as regards swimming up to the surface was observed between 2 and 5 DPH. On 3 DPH, the swim bladder of the first larvae was inflated. A similar behaviour was also observed in chub larvae, which acquired the ability to swim to the water surface on the fourth day after hatching, but unfortunately, there is no information on the distance they had to pass (Çalta 2000). Since $6 \mathrm{DPH}$, despite the fact that larvae had enough energy to lift even ten times from the bottom tank, they were not 
able to swim up to a distance which separated them from the water surface $(10 \mathrm{~cm})$. From that moment, the beginning of mortality was observed in larvae, and mortality appeared until $14 \mathrm{DPH}$.

Inability to inflate the swim bladder is quite a common phenomenon in larvae kept under controlled conditions (Battaglene and Talbot 1990; Çalta 2000; Woolley and Qin 2010). However, the moment of inflating the bladder is the major and the most critical moment related to the development of larvae of many fish species. Specimens without an inflated swim bladder have difficulties with preying. Moreover, they lose a lot of time and energy in maintaining a vertical position, which contributes to a higher mortality rate (Battaglene and Talbot 1990; Tander et al. 1995; Czesny et al. 2005). During the observation of the burbot larvae, it was recorded that inflation of swim bladder, most likely, took place when larva swims up to the water surface and takes a gulp of the air. Because larvae made more than one effort to swim up, it is highly probable that they have to take more than one gulp until they properly fill their swim bladder. It was also recorded that in burbot larvae, inflation of the swim bladder began on the $3 \mathrm{DPH}$, when $17 \%$ of larvae with an inflated bladder were observed. From this moment, both the mean volume of bladder as well as the number of larvae with inflated bladders constantly increased. Nevertheless, $100 \%$ of larvae with inflated bladders were recorded only on the last day of observation (15 DPH). This was probably related with the end of mortality of the larvae which were not able to inflate their swim bladder. Starting at $6 \mathrm{DPH}$, an increase in mortality was observed among the larvae which did not inflate the bladder, and on $15 \mathrm{DPH}$, this rate amounted to about $70 \%$ (in the first year of observation) and about $60 \%$ (in the second year of observation). Kujawa et al. (1999, 2002b), Kucharczyk et al. (2004) and Żarski et al. (2009) also reported high mortality of burbot larvae during the period of rearing under controlled conditions, sometimes reaching even $90 \%$. Therefore, the results obtained in this research confirm previous reports that high mortality is one of the biggest problems in larviculture of this species. Those authors suggested that such high mortality could result from the failure of swim bladder inflation. The results obtained in this study confirm the fact of a high mortality rate of larvae with non-inflated swim bladders. However, it is still not clear why some larvae are not able to inflate the swim bladder. The results obtained suggest that the failure to inflate the bladder in burbot is a consequence of the low quality of larvae. For example, in the Eurasian perch, the high percentage of larvae which did not inflate their swim bladder was closely correlated to their low quality (Źarski et al. 2011b). Thus, the presented data indicate the need of further researches related with this phenomenon.

Under controlled conditions, the quality of larvae is most often conditioned by the brood fish diet (e.g. Henrotte et al. 2008) or the effectiveness of reproduction procedures, where hormonal stimulation may affect egg quality (e.g. Ako et al. 1994). However, larvae in this study originated from brood fish caught in the natural environment, and females ovulated spontaneously (without hormonal stimulation). In addition, incubation was carried out at the optimum temperature (Wolnicki et al. 2002; Harzevili et al. 2004). Thus, it can be assumed that in this study, the quality of larvae was affected by other factors, which cannot exclude the biological conditions of this species. High mortality among burbot larvae was also observed under natural conditions, where it ranged from $40 \%$ (Schran 2000) to almost $90 \%$ (Ghan and Sprules 1991). Under natural conditions, burbot larvae choose shallow places for their first stage of life (Kjellman 2003; Donner and Eckmann 2011; Koporikov and Bogdanov 2011). On the other hand, the present research revealed that a 10-cm tank was too deep from day 5 for the larvae to swim up to the surface. Consequently, it seems 
that under controlled conditions, until the moment of swim bladder inflation, larvae should be kept in shallow (max. $10 \mathrm{~cm}$ deep) tanks. Nevertheless, the aspect of the optimum depth of the tank and the time when larvae could still fill their bladder requires more precise observation.

For a cost-effective rearing of fry-stocking material as well as for an economic conditions and profitability of the production, observation and knowledge of biological changes at the moment when exogenous feeding begins is very important element (Engrola et al. 2010). This has a huge impact on later physiology, ecology and behaviour of juveniles and adult fish (Peňáz 2001). Absorption of yolk sac content is gradual and to a large extent depends on temperature (Snyder 1976). The results obtained indicate that the yolk sac of the burbot is relatively short and high, sometimes resembles a sphere. It is also characterized by a presence of a large oil droplet, which was about $30 \%$ of the entire sac at hatching (0 DPH). This differentiates it from yolk sacs of the larvae of other river freshwater fish, which are strongly elongated, and the oil droplet is not as big or sometimes it is not present at all (Laurila and Holopainen 1990; Çalta 2000; Żarski et al. 2011a). In the dace, Leuciscus leuciscus (L.), the yolk sac on the day of hatching makes up about $47 \%$ of the total length of the larvae, in the chub, it is over $60 \%$ (Kupren et al. 2008), while in the burbot, at the moment of hatching (0 DPH), the yolk sac accounted for only about $17 \%$ of the total length of the body. The spherical shape of the yolk sac of burbot larvae and a large oil droplet help the larvae to take up a vertical position in the water. This property makes burbot larvae similar to the larvae of marine fish species (von Herbing et al. 1996; Williams et al. 2004).

Burbot larvae utilized the yolk sac content quite evenly (Fig. 7). The absence of yolk in all larvae were observed on $13 \mathrm{DPH}$, while disappearance of the oil droplet, despite its lower initial volume, was observed 1 day later (up to $14 \mathrm{DPH}$ ). This suggests that fats are utilized by burbot larvae less effectively and that yolk is the first and the most important source of energy (Williams et al. 2004), whereas the oil droplet probably increases the buoyancy of the larvae. The presence of yolk in some burbot larvae even by day 13 of the development seems to be relatively long compared to larvae of the Cyprinidae, in which the absence of the yolk sac was observed by about day 8 post-hatching (El-Finky and Wieser 1988; Çalta 2000). Most probably, this depends on the temperature at which larvae appear in the natural environment. Burbot larvae hatch in the natural conditions when the water temperature is about $4{ }^{\circ} \mathrm{C}$ (Kjellman 2003; Paragamian and Wakkinen 2008; Donner and Eckmann 2011), while larvae of the Cyprinidae appear at temperatures above $10{ }^{\circ} \mathrm{C}$ (Laurila and Holopainen 1990; Petering and Johnson 1991; Müller-Belecke et al. 2002). The research carried out on cod larvae found that larvae reared at $5{ }^{\circ} \mathrm{C}$ maintained the yolk sac until $13 \mathrm{DPH}$, and larvae reared at $10^{\circ} \mathrm{C}$ almost completely resorbed the yolk sac already on 5 DPH (von Herbing et al. 1996).

In the larviculture, the moment of exogenous food supply is crucial. Too early supply of food when not all larvae are able to take exogenous food can lead to size differentiation, which in the case of predatory fish (as for example the burbot) can result in intensified cannibalism (e.g. Baras et al. 2003). On the other hand, a late supply of food can bring about irreversible changes in the alimentary system, as a result of exceeding the so-called point of no return (PNR), after which larvae are not able to digest ingested food (e.g. Blaxter and Ehrlich 1974). In the research carried out at 5 DPH (2 days after swim bladder inflation), $10 \%$ of the larvae were able to take the first exogenous food (Artemia sp. nauplii) (Fig. 5). At that time, larvae had not completely used their endogenous nutritional material. The initiating of feeding by larvae even before resorption of the yolk sac was also 
observed in other species of fish (Urho 2002; Williams et al. 2004; Żarski et al. 2011a). The obtained results suggest that in larviculture of this species, the last moment the burbot larvae should be given exogenous food is most probably on day 10 of the development. After this day, the percentage of larvae which still had the yolk sac rapidly decreased (Fig. 5).

The results obtained confirm previous reports that high mortality is one of the major problems in larviculture of this species. They also suggest that this can be conditioned by biological factors, which, however, requires further research. Nevertheless, the data presented indicate that during the first $15 \mathrm{DPH}$, particular care should be preserved in intensive rearing of burbot larvae. They should be provided with a low depth of the water column (up to $10 \mathrm{~cm}$ ) and the food supply should start on $9-10 \mathrm{DPH}$ at $12{ }^{\circ} \mathrm{C}$. The results obtained can significantly increase the efficiency of rearing burbot larvae under controlled conditions, both for restocking and intensive aquaculture purposes.

Acknowledgments The study was financed by the project "Innovations in finfish aquaculture with special references to reproduction" (acronym: InnovaFish), Operational Programme Sustainable Development of the Fisheries Sector and Coastal Fishing Areas 2007-2013 (OR14-61724-OR1400003/09/10/11).

Open Access This article is distributed under the terms of the Creative Commons Attribution License which permits any use, distribution, and reproduction in any medium, provided the original author(s) and the source are credited.

\section{References}

Ako H, Tamaru CS, Lee C-S (1994) Chemical and physical differences in milkfish (Chanos chanos) eggs from natural and hormonally induced spawns. Aquaculture 127:157-167

Babiak I, Mandiki SNM, Ratsinjomanana K, Kestemont P (2004) Initial weight and its variation in postlarval Eurasian perch affect quantitative characteristics of juvenile cohorts under controlled conditions. Aquaculture 234:263-276

Baras E, Kestemont P, Melard C (2003) Effect of stocking density on the dynamics of cannibalism in sibling larvae of Perca fluviatilis under controlled conditions. Aquaculture 219:241-255

Battaglene SC, Talbot RB (1990) Initial swim bladder inflation in intensively reared Australian bass larvae, Macquaria movemaculeata (Steindachner) (Perciformes: Percichtyidae). Aquaculture 86:431-442

Blaxter JHS, Ehrlich KF (1974) Changes in behavior during starvation of herring and plaice larvae. In: Blaxter JHS (ed) The early life history of fish. Springer, New York, pp 575-588

Çalta M (2000) Morphological development and growth of chub, Leuciscus cephalus (L.), larvae. J Appl Ichthyol 16:83-85

Czesny SJ, Grae BDS, Dettmers JM (2005) Ecological Consequences of swim bladder noninflation for larval yellow perch. Trans Am Fish Soc 134:1011-1020

Dąbrowski K (1984) The feeding of fish larvae, the present "state of the art" and perspectives. Reprod Nutr Dev 24:807-833

Donner MT, Eckmann R (2011) Diel vertical migration of larval and early-juvenile burbot optimises survival and growth in a deep, pre-alpine lake. Freshw Biol 56:916-925

Egloff M (1996) Failure of swim bladder inflation of perch, Perca fluviatilis L., found in natural populations. Aquat Sci 58:15-23

El-Finky N, Wieser W (1988) Larval styles of development gills and muscles in larval cyprynids (Cyprynidae: Teleostei). J Fish Biol 33:135-145

Engrola S, Dinis MT, Conceicao LEC (2010) Senegalese sole larvae growth and protein utilization is depressed when co-feed high levels of inert diet and Artemia since firs feeding. Aquac Nutr 16:457-465

Fisher P (1999) Otolith microstructure during the pelagic, settlement and benthic phases in burbot. J Fish Biol 54:1231-1234

Fuiman LA, Cowan JH Jr (2003) Behaviour and recruitment success in fish larvae: repeatability and covariation of survival skills. Ecology 84:53-67 
Galavíz MA, García-Gasca A, Drawbridge M, Álvarez-González CA, Lopez LM (2011) Ontogeny of the digestive tract and enzymatic activity in white seabass, Atractoscion nobilis, larvae. Aquaculture 318:162-168

Ghan BD, Sprules WG (1991) Early life history and ecology of larval burbot (Lota lota). Verhandlungen des Internationalen Verein Limnologie 24:2377-2381

Grodziński Z (1971) Anatomia i embriologia. ryb. PWRiL, Warszawa

Hardy R, Paragamian VL, Neufeld MD (2008) Zooplankton communities and burbot relative abundance of some oligotrophic lakes of Idaho, USA and British Columbia. Can Am Fish Soc Symp 59:79-89

Harzevili AS, De Chareloy D, Auwerx A, Vught I, Van Slycken J, Dhert P, Sorgeloos P (2003) Larval rearing of burbot (Lota lota L.) using Brachionus calyciflorus rotifer as started food. J Appl Ichth 19:84-87

Harzevili AS, Dooremont I, Vught I, Auwerx J, Quataert P, De Charleroy D (2004) First feeding of burbot, Lota lota (Gadidae, Teleostei) larvae under different temperature and light conditions. Aquac Res 35:49-55

Henrotte E, Overton JL, Kestemont P (2008) Effects of dietary n-3 and n-6 fatty acids levels on egg and larval quality of Eurasian perch. Cybium 32:271-272

Jensen NR, Anders PJ, Hoffman CA, Porter LS, Island SC, Cain KD (2011) Performance and macronutrient composition of age-0 burbot fed four diet treatments. N Am J Aquac 73:360-368

Jones FRH, Marshall NB (1952) The structure and functions of the teleostean swimbladder. Biol Bull 28: $16-83$

Kjellman J (2003) Growth and recruitment of burbot (Lota lota). Academic dissertation in Fishery Science, Vaasa, $25 \mathrm{pp}$

Kjellman J, Eloranta A (2002) Field estimation of temperature-depend processes: case growth of young burbot. Hydrobiology 48:187-192

Koporikov AR, Bogdanov VD (2011) Spatial and biotopic distribution patterns of semianadromous burbot, Lota lota L. (Lotidae), early larvae in the lower Ob floodplain. Russ J Ecol 42:339-343

Kucharczyk D, Kujawa R, Mamcarz A, Skrzypczak A, Furgała-Selezniow G, Targońska-Dietrich K (2004) Zootechnical parameters of rearing burbot larvae and juveniles. In: Elevage de la lotte (Lota lota): Recherche et perspectives, Nancy, pp 6-11

Kujawa R, Kucharczyk D, Mamcarz A (1999) The rearing methods of burbot (Lota lota L.) fry under controlled conditions. Eur Aquac Soc Special Public 27:135-136

Kujawa R, Kucharczyk D, Mamcarz A, (2002a) Miętus. pp 96 Wyd. IRS

Kujawa R, Kucharczyk D, Mamcarz A (2002b) Biotechnika wychowu miętusa (Lota lota L.) w warunkach kontrolowanych. In: Wylęgarnia 2001-2002. pp. 77-87.Wyd. IRS

Kupren K, Mamcarz A, Kucharczyk D, Prusińska M (2008) Changes in morphometric parameters in selected early ontogenic stages of three fish species from the genus Leuciscus (Teleostei, Cyprynidae). Arch Pol Fish 16:421-436

Lauri U, Lappalainen J, Kjellman J, Hudd R (1998) Occurrence of burbot (Lota lota) larvae in relation to $\mathrm{pH}$. The International Congress on the Biology of Fish, Baltimore, pp 5-8

Laurila S, Holopainen I (1990) Features of embryonic and larval development of crucian carp, Carassius carassius (L.), with a note on species identification. Ann Zool Fen 27:361-367

Mark W, Hofer R, Wieser W (1987) Diet spectra and resource partitioning in the larvae and juveniles of three species and six cohorts of cyprynids from subalpine lake. Oecologia 71:388-396

McPhail JD, Paragamian VL (2000) Burbot biology and life history. In: Burbot biology, ecology and management, Washington, USA, pp 11-23

Müller-Belecke A, Ohara K, Koedprang W, Hörstgen-Schwark G, Taniguchi N (2002) Environmental influence on quantitative traits of naturally isogenic lines of ginbuna Carassius langsdorfii. Aquaculture 203:251-262

Øyvind JH, Puvanendran V, Jřstensen JP, Ous C (2011) Effects of dietary levels and ratio of phosphatidylcholine and phosphatidylinositol on the growth, survival and deformity levels of Atlantic cod larvae and early juveniles. Aquac Res 42:1026-1033

Paragamian VL, Hansen J (2009) Rehabilitation needs for burbot in the Kootenai River, Idaho USA and British Columbia Canada. N Am J Fish Manag 29:768-777

Paragamian VL, Wakkinen DV (2008) Seasonal movement of burbot in relation to temperature and discharge in the Kootenai River, Idaho, USA and British Columbia. Can Am Fish Soc Symp 59:55-77

Paragamian VL, Pyper BJ, Daigneault MJ, Beamesderfer RCP, Ireland SC (2008) Population dynamics and extinction risk of burbot in the Kootenai river, Idaho USA and British Columbia Canada. Am Fish Soc Symp 59:213-234

Peňáz M (2001) A general framework of fish ontogeny: a review of the on-going debate. Folia Zool 50:241-256 
Petering RW, Johnson DL (1991) Distribution of fish larvae among artificial vegetation in a diked Lake Erie Wetland. Wetlands 11:123-138

Schran ST (1983) Seasonal movements and mortality estimates of burbot in western Lake Superior. In: Bureau of fish management, pp 11. Wisconsin Department of Natural Resources

Schran ST (2000) Seasonal movement and mortality estimates of burbot in Wisconsin waters of Western Lake Superior. In: Burbot biology, ecology and management,Washington USA, pp 81-89

Scott WB, Crossman EJ (1973) Freshwater fishes of Canada. Bull Fish Res Board Can 184:966 Ottava

Snyder DE (1976) Terminologies for intervals of larval fish development. In: Great lakes fish egg and larval identification Ann Arbor pp 41-58

Tander A, Harel M, Koren WM, Kolkovski S (1995) Broodstock and larvae nutrition in gilthead seabream, Sparus aurata: new findings on its mode of involvement in improving growth, survival and swim bladder inflation. Isr J Aquac Bamidgeh 47:95-111

Trabelsi A, Gardeur J-N, Teletchea F, Fontaine P (2011) Effects of 12 factors on burbot Lota lota (L., 1758) weaning performances using fractional factorial design experiment. Aquaculture 316:104-110

Urho L (2002) Characters of larvae-what are they? Folia Zool 51:168-186

von Herbing H, Boutilier RG, Miyake T, Hall BK (1996) Effects of temperature on morphological landmarks critical to growth and survival in larval Atlantic cod (Gadus morhua). Mar Biol 124:593-606

Wang N, Mandiki SNM, Henrotte E, Bouyahia A-G, Mairesse G, Rougeot C, Melard C, Kestemont P (2009) Effect of partial or total replacement of forage fish by a dry diet on the quality of reproduction in pikeperch, Sander lucioperca. Aquac Res 40:376-383

Williams K, Papanikos N, Phelps RP, Shardo JD (2004) Development, growth, and yolk utilization of hatchery-reared red snapper Lutjanus campechanus larvae. Mar Ecol Prog Series 275:231-239

Wocher H, Harsányi A, Schwarz JF (2011) Larviculture of burbot (Lota lota L.): larval rearing using Artemia and weaning onto dry feed. Aquac Res, 1-8

Wolnicki J (2001) Szanse masowej produkcji materiału zarybieniowego miętusa Lota lota (L.) w świetle ostatnich prac badawczych w Polsce i za granicą. Przegląd Rybacki 2:35-38

Wolnicki J, Kamiński R, Myszkowski L (2002) Temperature-influenced growth and survival of burbot Lota lota (L.) larvae fed live food under controlled conditions. Arch Pol Fish 10:109-113

Woolley LD, Qin JG (2010) Swim bladder inflation and its implication to the culture of marine finfish larvae. Rev Aquac 2:181-190

Żarski D, Sasinowski W, Kucharczyk D, Kwiatkowski M, Krejszeff S, Targońska K (2009) Mass initial rearing of burbot Lota lota (L.) larvae under controlled conditions. Pol J Nat Sci 24:76-84

Żarski D, Kucharczyk D, Sasinowski W, Targońska K, Mamcarz A (2010) The influence of temperature on successful reproductions of burbot, Lota lota (L.) under hatchery conditions. Pol J Nat Sci 25:93-105

Żarski D, Kupren K, Targońska K, Krejszeff S, Furgała-Selezjon G, Kucharczyk D (2011a) The effect of initial larval stocking density on growth and survival in common barbell Barbus barbus (L.). J Appl Ichthyol 27:1155-1158

Żarski D, Palińska K, Targońska K, Bokor Z, Kotrik L, Krejszeff S, Kupren K, Horváth Á, Urbányi B, Kucharczyk D (2011b) Oocyte quality indicators in Eurasian perch, Perca fluviatilis L., during reproduction under controlled conditions. Aquaculture 313:84-91 